\title{
DOMINIK BORATYN
}

Uniwersytet Rzeszowski

ORCID ID: https://orcid.org/0000-0003-2335-7515

\section{Dwie rocznice w historiografii i edukacji historycznej}

[recenzja książki Dwie rocznice. Obraz wojny polsko-bolszewickiej i zbrodni katyńskiej w historiografii i edukacji historycznej]

\section{Two anniversaries in historiography and historical education}

[book review Dwie rocznice. Obraz wojny polsko-bolszewickiej i zbrodni katyńskiej w historiografii i edukacji historycznej]

\section{Два юбилея в историографии и историческом образовании \\ [рецензия книги Dwie rocznice. Obraz wojny polsko-bolszewickiej i zbrodni katyńskiej w historiografii i edukacji historycznej]}

ok 2020, zarówno w Polsce, jak i na świecie, zostanie zapamiętany przede
wszystkim jako czas pandamii koronawirusa SARS-CoV-2, który był odpowiedzialny za chorobę COVID-19. Wirus w znaczący sposób wpłynął na życie społeczne i ekonomiczne w wielu państwach na świecie. Doprowadził m.in. do kryzysu ekonomicznego oraz wzrostu nierówności społecznych (Długosz, 2020, s. 1). Pandemia stała się zatem najważniejszym tematem debat oraz dyskusji zarówno wśród polityków, dziennikarzy, przedsiębiorców oraz większości obywateli. W cieniu pandemii, w 2020 roku, w Polsce przypadły rocznice dwóch ważnych wydarzeń historycznych. Mowa tutaj o 100. rocznicy Bitwy Warszawskiej, która rozegrała się w sierpniu 1920 roku i w efekcie dała zwycięstwo Polsce w wojnie z bolszewikami, oraz 80. rocznicy zbrodni katyńskiej, czyli sowieckiego mordu dokonanego na polskich oficerach 
przebywających w obozach dla jeńców wojennych w 1940 roku. Należy zatem zauważyć, że wskazane powyżej rocznice stanowią swego rodzaju kontrast. Pierwsza jest symbolem zwycięstwa oraz męstwa polskich żołnierzy, którzy oddali życie w obronie niepodległości i suwerenności granic II RP. Bitwa Warszawska ma również uniwersalne przesłanie o konieczności przeciwstawiania się dyktaturom i skuteczności poświęceń w obronie wolności. Angielski dyplomata lord Edgar Vincent D’Abernon opisał Bitwę Warszawską następującymi słowami „Współczesna historia cywilizacji zna mało wydarzeń posiadających znaczenie większe od bitwy pod Warszawą w roku 1920. Nie zna zaś ani jednego, które byłoby tak niedocenione" (Bitwa Warszawska... 2020). Druga rocznica stanowi symbol tragedii narodu polskiego. $Z$ polecenia najwyższych władz Związku Sowieckiego, z Józefem Stalinem na czele, funkcjonariusze NKWD dokonali masowych zabójstw na około 22 tys. polskich obywateli, w tym m.in. na oficerach Wojska Polskiego, policjantach i osobach cywilnych należących do elity II Rzeczypospolitej. Prawdę o Katyniu fałszowano przez lata i dopiero w 1990 roku władze Związku Sowieckiego oficjalnie przyznały się do ludobójstwa (Guzowska, 2020; Dobroczyński, Marszałek-Kawa, 2005).

Mając na uwadze znaczenie tych dwóch niewątpliwie ważnych dla historii Polski wydarzeń, należy zwrócić uwagę na pozycje naukowe podejmujące problematykę Bitwy Warszawskiej oraz zbrodni katyńskiej. W pierwszej kolejności należy zaznaczyć, że w literaturze przedmiotu Bitwa Warszawska i zbrodnia katyńska traktowane są jako odrębne wydarzenia. Jest to zresztą uzasadnione bowiem obydwa wydarzenia dzieli 20 lat, a każde z nich niejednokrotnie było przedmiotem badań oraz rozważań naukowych. W odniesieniu do Bitwy Warszawskiej warto wymienić pozycję m.in.: Normana Davisa (2011) i Adama Zamoyskiego (2020), a w przypadku zbrodni katyńskiej monografię Katyń 1940. Walka o prawdę pod redakcją Wojciecha Lisa (2012).

Omawiana w niniejszej recenzji pozycja Dwie rocznice. Obraz wojny polsko-bolszewickiej i zbrodni katyńskiej w historiografii i edukacji historycznej jest zatem wyjątkowa już przez sam fakt, iż omawia obydwa wydarzenia, tj. Bitwę Warszawską i zbrodnie katyńską, traktując jednocześnie o trudnych relacjach polsko-rosyjskich na przestrzeni dziejów. Monografia pod redakcją Marka Białokura, Joanny Raźniewskiej i Krystyny Steckiej zawiera osiem rozdziałów poświęconych zagadnieniom związanym z dwoma wspomnianymi wyżej wydarzeniami. 
Monografię otwiera tekst Joanny Raźniewskiej pt. „Dwóch młodych chłopaków poszło na wojnę". W publikacji autorka dokonała porównania przebiegu wojny polsko-bolszewickiej na podstawie zapisków z pamiętników walczącego po stronie polskiej Stanisława Rembeka oraz walczącego po stronie bolszewików Izaaka Babla. Jest to jeden z najciekawszych rozdziałów w całej pozycji, ponieważ zawiera oryginalne zapisy oraz relacje dwóch młodych żołnierzy walczących po przeciwnych stronach. Zarówno relacje Rembeka jak i Babla są wypełnione egzystencjalnym pesymizmem. Spisywane w wolnych chwilach dzienniki dwóch młodych żołnierzy są świadectwem ludzkich trudów, emocji, codzienności oraz cierpienia, a także refleksją nad tragedią wojny i jej skutkami.

Rozdział drugi pt. „Sytuacja ludności na Kresach Wschodnich w czasie wojny polsko-bolszewickiej", którego autorką jest prof. Dorota Sula, prezentuje tragiczne losy cywilów zamieszkujących na obszarach objętych wojną. Należy zauważyć, że publikacja nie jest jednostronną relacją prezentującą wyłącznie zbrodnie popełniane przez bolszewików. W artykule znajdziemy też m.in. fragment listu metropolity lwowskiego Andrzeja Szeptyckiego, w którym to duchowny informuje Józefa Piłsudskiego o niewłaściwym traktowaniu ludności rusińskiej przez Polaków. Jako całość artykuł koncentruje się na ukazaniu tragizmu wojny, a także podkreśla, że jej największą ofiarą zawsze jest ludność cywilna (niezależnie od narodowości czy religii). Warto również zauważyć, że autorka zwraca uwagę na to, że ludność zamieszkująca Kresy Wschodnie stanowiła mozaikę narodową, kulturową i religijną, a część tych osób postrzegała zarówno bolszewików, jak i Polaków jako okupantów.

Rozdział trzeci autorstwa Andrzeja Prajela zatytułowany „Katyń - prawda i kłamstwo" w całości został poświęcony zagadnieniu zbrodni katyńskiej. W publikacji autor przedstawił historię zbrodni katyńskiej, jednocześnie wskazując, że samo pojęcie „Katyń” to nie tylko mord dokonany na elitach II RP, ale także 50 lat kłamstwa i zafałszowywania historii przez Związek Sowiecki. Artykuł został wzbogacony o fragmenty dokumentów i materiały archiwalne zawierające informację na temat całej zbrodni. $Z$ punktu widzenia czytelnika jest to zatem niezwykła wartość dodana, która nadaje publikacji sporo realizmu.

Kolejnym artykułem zamieszczonym w monografii był tekst Przemysława Jagieły pt. „,Polacy na Kresach Wschodnich. Formy i skala represji 1939-1941 w przeddzień radzieckiej agresji”. Publikacja jest o tyle ważna, iż nie sposób 
mówić lub pisać o relacjach polsko-radzieckich bez uwzględnienia ogromu tragedii, jakich doświadczyli Polacy ze strony Związku Sowieckiego w omawianym okresie. W artykule opisano różne formy represji, jakich doświadczyli polscy obywatele zarówno cywilni, jak i wojskowi. Przemysław Jagieła opisał m.in. jak wyglądały aresztowania, deportacje oraz życie codzienne jeńców wojennych wziętych do niewoli radzieckiej. Atutem artykułu jest jego ponadczasowy charakter. Świadczyć może o tym fakt, iż pomimo upływu 10 lat od publikacji P. Jagieły ciągle powstają nowe prace, które również poruszają problematykę represji stosowanych przez ZSRR względem ludności polskiej (m.in. Matelski, 2017; Boratyn, 2020).

Kolejny artykuł autorstwa Doroty Musiał został zatytułowany „Józef Czapski i jego misja. Próba rekonstrukcji losów polskich jeńców wojennych”. Publikacja w całości została poświęcona osobie Józefa Czapskiego - malarza oraz pisarza i oficera Wojska Polskiego, odznaczonego Krzyżem Srebrnym Orderu Virtuti Militari, który był autorem m.in. dwóch publikacji stanowiących swoiste kompendium wiedzy o okrucieństwach radzieckiego systemu władzy. Mowa tutaj o Na nieludzkiej ziemi (pierwsze wydanie w 1949 roku) i Wspomnieniach starobielskich (data powstania: 1943 r.). Postać Józefa Czapskiego idealnie wpisuje się w tematykę recenzowanej monografii. Czapski był uczestnikiem wojny polsko-bolszewickiej, a za udział w wyprawie kijowskiej został odznaczony m.in. wspomnianym wcześniej Orderem Virtuti Militari. Następnie walczył we wrześniu 1939 roku i trafił do niewoli radzieckiej. Osadzony w obozie w Starobielsku był jednym z 79 ocalonych ze zbrodni katyńskiej. Uniknął śmierci, a na mocy układu Sikorski-Majski został objęty amnestią. Przedostał się do rejonów formowania Polskich Sił Zbrojnych. Był żołnierzem 2 Korpusu Polskiego. Po wojnie pozostał na emigracji. Wspomnienia napisane przez Czapskiego sprawiły, że był on znienawidzonym wrogiem Polski Ludowej. Postać Józefa Czapskiego łączy dwie omawiane na wstępie rocznice, a jego postawa oraz działalność mogą być wzorem do naśladowania dla młodego pokolenia.

Kolejny rozdział monografii stanowią eseje uczniów Liceum Ogólnokształcącego nr III im. Marii Skłodowskiej-Curie w Opolu nagrodzone w konkursie pt. „PAMIĘĆ SILNIEJSZA NIŻ PROPAGANDA. Świadomość zbrodni katyńskiej w PRL-u”. Eseje zostały przygotowane przez Milenę Kowalską, Annę Marię Podymę oraz Piotra Polaka. Prace zostały poświecone 
kwestii świadomości o zbrodni katyńskiej w realiach Polski rządzonej przez komunistów w latach 1945-1989. Uzupełnieniem młodzieżowej części monografii jest scenariusz uczniowskich warsztatów historycznych „Katyń w kulturze i popkulturze", przygotowany przez nauczyciela historii, wiedzy o społeczeństwie i edukacji dla bezpieczeństwa z III LO w Opolu Artura Szymczaka oraz uczniów klasy III Katarzyny Dziaduś i Łukasza Prządo.

Ostatnim rozdziałem monografii Dwie rocznice... jest publikacją prof. Marka Białokura z Uniwersytetu Opolskiego pt. „, Od tryumfu do tragedii. Rok 1920 i 1940 w historii stosunków Rzeczypospolitej Polskiej z Rosją Sowiecką. Szkic historyczny dla młodzieży licealnej”. Artykuł zawiera najważniejsze fakty, opinie historyków, a także pozycje bibliograficzne dotyczące wydarzeń związanych z wojną polsko-bolszewicką oraz zbrodnią katyńską. Autor stworzył swego rodzaju zbiór najważniejszych informacji, przydatnych dla wszystkich osób chcących zdobyć lub utrwalić wiedzę na temat omawianych w monografii wydarzeń. Jest to pozycja szczególnie przydatna i interesująca dla wszystkich, którzy poszukują wiedzy o Bitwie Warszawskiej (tryumfie) i zbrodni katyńskiej (tragedii), warta polecenia nie tylko uczniom, ale także studentom.

Niewątpliwie wartością recenzowanej pracy jest to, że zawarte w niej artykuły są dziełem nie tylko pracowników naukowych (m.in. prof. Marek Białokur, prof. Dorota Sula) i osób legitymujących się wyższym wykształceniem, w tym nauczycieli szkół średnich oraz pracowników muzeów, ale także uczniów i absolwentów Liceum Ogólnokształcącego nr III w Opolu. Monografia stanowi zatem zbiór publikacji napisanych zarówno przez badaczy, praktyków, jak i miłośników historii najnowszej. Kolejną cechą charakterystyczną publikacji jest jej przystępny język. Można zatem zauważyć, że Dwie rocznice... są skierowane nie tylko do przedstawicieli środowisk akademickich, ale także do znacznie szerszego grona odbiorców, w tym uczniów, studentów i osób chcących pogłębić swoją wiedzę z najnowszej historii Polski.

Kolejnym atutem opracowania jest jego ponadczasowy charakter. Teksty autorów traktują o ważnych wydarzeniach historycznych. Bitwa Warszawska i zbrodnia katyńska są częściami naszej tożsamości narodowej, a propagowanie i upowszechnianie wiedzy na ich temat jest nie tylko obowiązkiem, ale również wyzwaniem dla obecnych i przyszłych pokoleń Polaków. Dodatkowo 
warto zauważyć, że część artykułów zawiera informacje, które stanowią swego rodzaju novum, np. dzienniki Rembeka i Babla.

Reasumując, Dwie rocznice... są pozycją, którą można polecić wszystkim miłośnikom historii Polski XX wieku, ale także uczniom i studentom kierunków takich jak historia czy politologia, chcących pogłębić swoją wiedzę na temat Bitwy Warszawskiej oraz wojny polsko-bolszewickiej, jak również zbrodni katyńskiej.

\section{MGR DOMINIK BORATYN}

Instytut Nauk o Polityce

Uniwersytet Rzeszowski

al. Rejtana 16c, 35-959 Rzeszów

dk.boratyn@gmail.com

\section{Bibliografia}

Białokur, M., Raźniewska-Krys, J., Stecka, K. (2010). (red.). Dwie rocznice. Obraz wojny polsko-bolszewickiej i zbrodni katyńskiej w historiografii i edukacji historycznej. Toruń: Wydawnictwo Adam Marszałek.

Bitwa Warszawska - zwycięstwo Polski dla wolności Europy. Gov.pl. (2020, 15 sierpnia). Pobrane z: https://www.gov.pl/web/chiny/bitwa-warszawska-100-lat.

Boratyn, D. (2020). Losy Polaków wywiezionych na Syberie we wspomnieniach zesłańców. W: J. Kur-Kononowicz (red.). Syberia. Przeszłość i teraźniejszość (19-29). Rzeszów: Uniwersytet Rzeszowski.

Davis, N. (2011). Orzeł Biały, Czerwona Gwiazda. Kraków: Społeczny Instytut Wydawniczy „Znak”.

Długosz, P. (2020). Społeczne skutki pandemii COVID-19 wśród Polaków. Pobrane z: https://ifis.up.krakow.pl/wp-content/uploads/sites/9/2020/10/Spo\%C5\%82eczne-skutki-pandemii-w\%C5\%9Br\%C3\%B3d-Polak\%C3\%B3w_raport1.pdf.

Dobroczyński, M., Marszałek-Kawa, J. (red). (2005). Skomplikowane stosunki Polaków i Rosjan. Toruń: Wydawnictwo Adam Marszałek.

Guzowska, S. (2020). 80. rocznica zbrodni katyńskiej. Pobrane z: https://www.wojsko-polskie.pl/kgzw/articles/aktualnosci-w/2020-04-107-80-rocznica-zbrodni-katynskiej/. Lis, W. (2012). (red.). Katyń 1940. Walka o prawdę. Toruń: Wydawnictwo Adam Marszałek. Matelski, D. (2017). Polityka eksterminacji obywateli Drugiej Rzeczypospolitej przez Trzecią Rzeszę i Związek Sowiecki w latach 1939-1945, część II: Polityka Związku Sowieckiego. Nowa Polityka Wschodnia 4(15), 205-225.

Zamoyski, A. (2020). Warszawa 1920 Nieudany podbój Europy. Klęska Lenina. Kraków: Wydawnictwo Literackie. 